\title{
Ethnic Tourism as Knowing Other
}

\section{Olga V. Chistyakova}

\author{
Peoples' Friendship University of Russia (RUDN University) \\ 6, Miklukho-Maklaya Str., Moscow, 117198, Russian Federation
}

\begin{abstract}
The article is dedicated to considering ethnic tourism in its importance to comprehend modern cultures that are Others to the traveler's experience. In this regard, ethnic tourism is presented from the Other's cognition, i.e., the way of life of a nation, its religious and ethnic values and traditions, historical past and legends, and geographical specificity of residence. Thus, the meaning of ethnic tourism is related to the human desire to discover other cultural and social spaces. Simultaneously, the article shows how another culture's perception affects the awareness of a tourist's identity. The author notes that ethnic tourism aims at fixing the distinctive features and specifics of people's life. Therefore, this type of tourism is most conducive to forming images and perceptions of ethnic and cultural diversity. The author substantiates the role of ethnic tourism to establish a dialogue of cultures in the modern world. Distinctive features of globalization, particularly travelers' continuous mobility, the conversation of ethnic groups, and the value-based mutual enrichment of peoples, have been deduced. Some theoretical approaches of Russian philosophers to the study of ethnic tourism are defined. The researcher emphasizes the idea of a correlation between ethnic cultures and religions. In this regard, early Christianity's theological ideas are conditioned in terms of their impact on the subsequent formation of pilgrimages and the modern religious tourism organization. The contemporary unity of ethnic culture and religiosity is vividly manifested in the uniqueness of the Old Believers' tradition of the Kerzhak resettlers living in the Altai Mountains. The article concludes that ethnicity should be acknowledged in any tourism organization, especially religious and pilgrimage types.
\end{abstract}

Keywords: philosophy of tourism, ethnic tourism, religious tourism, ethnic culture, pilgrimage, Byzantium, Altai Mountains

Funding and Acknowledgement of Sources. The reported study was funded by RFBR according to the research project № 20-011-00045 A “The Influence of Ethnocultural, Religious, Communicative, Educational and Migration Factors on the Development of the Contemporary Tourism Industry: Socio-Philosophical Inquiry."

\section{Article history:}

The article was submitted on 12.05.2020

The article was accepted on 11.08.2020

(c) Chistyakova O.V., 2020

This work is licensed under a Creative Commons Attribution 4.0 International License https://creativecommons.org/licenses/by/4.0/ 
For citation: Chistyakova O.V. Ethnic Tourism as Knowing Other. RUDN Journal of Philosophy. 2020; 24 (4): 720-729. DOI: 10.22363/2313-2302-2020-24-4-720-729

Interethnic and interreligious relations have a great impact on the social and cultural life of any country. Being the most crucial component of a country's socioeconomic sphere, the tourism industry cannot develop without proper considering the nature of these relations. This is especially significant for the polyethnic states, particularly for the Russian Federation, with inhabiting representatives of more than 190 ethnic groups, small-numbered and indigenous peoples. Each of them is in accord with their own cultural identity, formed based on religious history, shaping linguistic traditions, and economic and political peculiarities. The mentioned factors should be thoroughly scrutinized, especially in the sphere of organization, the religious and ethnic tourist destinations, for the successful evolvement of a country's tourism industry.

In the epoch of globalization, characterized by mobility and constant movement of peoples' flows, tourism is a kind of specific knowing and even scrutinizing the Other. However, for its part, comprehension of the Other means penetration into the depths of culture, religion, and a traveling person's civil consciousness. Indeed, to conceive one's identity in the contemporary dynamic world's complexity, it is necessary to reason the Other. The notion of Other may be reviewed in the philosophical terms as something different, opposed, alternative a style of life, a diversity of religious and ethnic peculiarities of one's community, or a variety of values and moral norms. In this context, tourism can be substantiated as a specific center symbolically representing an ethnic heterogeneity of the global world and supporting peoples' interaction and reconciliation with dissimilar cultural and civic identifications.

On the level of the informative functioning, tourism can be defined as the process of organization and implementation of people's cognitive activity. In this sense, it contributes significantly to overcoming estrangement and taking down the insularity wall among ethnic communities, establishing in their stead the peaceful dialogue between cultures and even countries. Ethnic tourism plays a tremendous role in this process, reflecting many permanent transformations of the contemporary world. Essentially, ethnic tourism is an insight into the otherness of another culture, as well as the perception of the cultural distinctiveness and peculiarity. That assists significantly in both the formation of images and visions about the people's everyday culture and awareness of some meanings of its ethnic, religious, and civil identifications. This understanding of tourism assumes to have a cultural diversity of the contemporary world with simultaneous preservation of the ethnic and religious uniqueness despite the developed tendency of the globalizing unification of the cultures. A philosophically exciting sight on the tourism suggests Dean MacCannell. The American anthropologist stresses the specificity of social acceptance of the authentic cultures in the complex stratified society. He writes: " $<\ldots>$ tourism is a ritual, performing in accordance with various types of differentiation in a society" [1. P. 53]. 
Next, we discuss some particular characteristics of this "rite," taken from history and the global world, implemented by its ethnic means.

\section{Globalization and Ethnic Tourism: Knowing Self through the Other}

Globalization has many contexts and meanings. It may be represented in society in different ways: as a definite ideology, complexity of life, spreading of networking connections and virtual reality, total mediatization of mass (M. Castells, R. Debray), and even as a "performance" if we agree with Guy Debord's conception of modernity as a society of spectacle [2]. However, globalization is also associated with such an important social characteristic as endless flows of people traveling worldwide for various purposes, including educational and touristic. This movement of people is accompanied by the incessant mobility of all those structures and objects that create favorable conditions for voyages. John Urry, the author of the "mobile sociology" conception, emphasizing mobility as the most essential feature of the postmodern epoch, put into the spotlight: "These flows are seen as moving along various global 'scapes,' including the system of transportation of people by air, sea, rail, motorways and other roads. There is the transportation of objects via postal and other systems. $<\ldots>$ Various potential flows occur along these scapes. Thus people travel along transportation scapes for work, education and holidays. <...> Information, messages and images flow along various cables and between satellites. Messages travel along microwave channels from one mobile phone to another. These scapes and flows create new inequalities of access. What becomes significant is the 'relative', as opposed to the 'absolute', location of a particular social group or town or society in relationship to these multiple scapes. They pass by some areas while connecting others along information and transportation rich 'tunnels'. These can compress the distances of time and space between some places while enlarging those between others" [3. P. 4-5].

The boundless mobility of people, traveling at present days utilizing technologically advanced transport, puts the location of a particular social group, settlement, or even a country in a relative position towards the global world's infinity. Understanding of relativity in the perception of distance to reach a particular tourist object, a monument of ethnic culture, or religious worship places almost eliminates the feeling of the space immensity, "compresses" the Universe and allows to travel freely over the world and even out of its scope. (A space tourism is becoming more and more favorable in economies of some countries. For example, the American company Virgin Galactic is vigorously planning to organize the tourist suborbital and orbital flights. In this sense, the recent launch of the SpaceX company's first private rocket "Crew Dragon" in the United States has made the space tourism quite tangible shortly).

Though the objective of all travels, even in space tourism, is the comprehension of other geographical and cultural places, ethnic and religious values, peoples' traditions, and habits that differ from a traveling person's authentic culture. Essentially the tourists perceive the images and symbols of other ethnic 
cultures and countries, but, at the same time, understanding a different kind of sociality appears to be more significant than just contemplating a monument or local sightseeing. We follow the position of Dean MacCannell stressing: "The actual act of communion between tourist and attraction is less important than the image or the idea of society that the collective act generates. $\langle\ldots\rangle$ of cause, the visit is indispensable to the image. A specific act of sightseeing is weightless and, at the same time, the ultimate reason for the orderly representation of the social structure of modern society in the system of attractions" [4. P. 15]. Since it is entirely human nature to compare and match the phenomena of different cultures, it turns out that tourism per se is the effective mean for reflection and knowing of a traveler's own ethnic identity and spirituality.

The mobility mentioned above means implementing a dialogue between diverse cultures and religions more than merely movement and interrelationship. Each traveler represents their own unique ethnic culture, having historically rooted religious identification and rituals. Therefore, ethnic tourists, initially aiming at knowing the uniqueness of other people's being, are quite constructive for establishing the peaceful interethnic and interreligious connections between different ethnic groups. Russian researchers Polyakova N.V. and Maksimov D.V. deeply emphasize: " $<\ldots>$ tourism should be considered as one of the structural elements of ethnicity and ethnic stratification as the global phenomena rather than something that exists outside of their scope. Tourism activity quite often changes relationships in the ethnic communities and merely attitude towards the state and other ethnic groups" [5. P. 260].

In general, tourism is one of the efficient social institutions, having its infrastructure and stratification. As such, it fulfills the dual function in the dialogical relationship of contemporary cultures. Tourism inspires the establishment and development of interethnic, interreligious, and social communications worldwide, and causes mutual enrichment by values among different ethnic groups. The ethnical differentiation of the present world assumes, and even induces an openness of ethnic communities and local cultural congregations to each other in globalization. In its turn, their extraversion determines the reciprocal exchange by the scientific knowledge, cultural artifacts, religious and secular ideas, IT-achievements, and so on. Therefore, almost every person's inner world is filled with images of other cultures and views about social life in different countries. However, even though globalization encourages the peoples' integration and their exchanging of the culture's attainments, there are dissimilarities, connotations, differences, and insularity among the diversity of the ethnic and religious groups in the world communicative processes. Paradoxically, but it is distinctiveness and otherness that endows ethnic societies' cultures with uniqueness and originality.

Philosophically, distinctiveness per se has always been and will continue to be the essential basis of any people's ethnic culture. However, both mutual rejection of cultures and the emergence of a dialogue of cultures are possible. In our opinion, tourism (primarily ethnic and religious) can help overcome alienation among individuals, ethnic societies, or religious organizations due to its communication 
function. With its focus on comprehending the Other, tourism establishes a dialogue between peoples as carriers of a specific ethnic culture, thereby contributing to people's mutual spiritual enrichment on a global scale. Indeed, to carry out tourist trips and establish communications with communities from other countries, people must produce intercultural universals and interreligious values, mutually acceptable for representatives of different (often alien to each other) cultures and religions. Each person must be open and take a step towards the Other. According to the stated ideas, each traveler initially realizes his intentions, making trips to comprehend another country's or region's ethnic culture. Otherwise, communications are impossible, mostly globally.

\section{Ethnic tourism: theoretical approaches to research}

In organizing tours and routes of an ethnic nature, first of all, the originality of a certain ethnic culture should be presented and advertised, the unique features of which are initially aimed not only at obtaining knowledge of a new country or a region but also at reflexive "asking" of the traveler about the meanings of his own identity. As noted previously, comprehension (by a random tourist) of a previously unknown place with the peculiarities of the religious, social, and everyday lives gives new opportunities for learning their history and culture. Therefore, in modern societies, the understanding of the importance of ethnic tourism increases naturally. Thematic conditionality and widespread demand for ethnic tourism are determined by globalization and, as a result, the intersection of cultures. The tourist-cognitive process acquires a dual character today: on the one hand, interest in the culture and life of other peoples is gaining more and more relevance, and on the other hand, attention deepens to the primordial sources of one's own culture, the spiritual foundations of one's ethnic past, its historical and religious traditions, and lost values. Along with the increase in interaction among countries, peoples' ethnic selfconsciousness, desire to "touch" their origin, and cognize the ethos and meanings of their existence are developing. All of this inevitably affects the content of ethnic tourism.

In studies on tourism and its management expectedly appears the question of the ethnic tourism's content. Russian philosopher N.A. Berkovich reveals the essential foundations of ethnic tourism by understanding ethnicity and ethnic cultures in modern societies. He distinguishes three modifications of ethnic tourism. The first type is associated with educational routes to national villages, museums, parks, and has a superficially friendly nature. "The second modification is actually ethnic tourism with a defining attitude to introversion, to meet the need for ethnicity, in ethnic socialization $\langle\ldots>$. Ethnic tourism of this modification is turned into the relict, anachronistic past, to the intergenerational, diachronic sources of archetypal, mentality, and behavioral stereotypes. Ethnic tourism allows one to reveal half-forgotten and lost semiotic, symbolic codes of meanings of ethnicity, to learn and comprehend your true cultural and genetic roots, genealogy, to reconstruct historical memory and thereby form own ethnic-national identity" [6. P. 7]. The 
third type of ethnic tourism is a long-term "ethnically extravagant" travel to create a "holistic ethnic geographic image of individual regions and other countries" [6. P. 8].

The most significant is the second semantic type of ethnic tourism since it is especially relevant for the reconstruction and restoration of each nation's historical memory and the course of global history. Ethnic tourism in its goal-setting is aimed at reviving the non-preserved (or forgotten) cultural meanings of peoples, their traditions, ideas, legends and myths, folklore, and behavioral norms. In this context, ethnic tourism could play a positive role in restoring the history of disappeared peoples and peoples on the verge of extinction.

However, we should emphasize that another nation's ethnic culture, attractive for tourists, may also turn out to be an artificially constructed image picture, a simulative tourist destination, in fact a simulacrum that does not have an original in its basis. In this case, cultural artifacts can be veiled "under ethnicity" to create an attractive tourist site and its mass sale. In other words, ethnic culture can be commercialized for profit. Russian researcher of tourism problems N.V. Mikhailova argues that in such conditions, an unrealistic "world order" is purposefully created to realize the primary goal of tourists - "getting out of the circle of everyday life." Suppose tourism becomes part of the "commercialized mass culture" [7. P. 103], then the constructed world order acquires an "imaginary," let us add - an illusory - character. "This order was created for you as a tourist, this is again your familiar world, but under the guise of another" [7. P. 103]. Of course, ethnic tourism has nothing to do with the goals of comprehending the history and culture of ethnic groups, which we spoke about previously.

Mass media play an important role in creating images of attractive or, on the contrary, unattractive tourist destinations. In the digital era, media are well stratified, have the latest technological means of creating and broadcasting information, rely on scientific methods of influencing the audience, have in their arsenal qualified editorial staff, operators, technical services, etc. Typically, mass media "provide" for the world's picture already in a person's mind. Thus, the created media images ideally correspond to the possible customer expectations [8]. This naturally correlates with the network, i.e., instant, broadcast, and dissemination of information. Therefore, it is not difficult for new digital media to create image representations of specific tourist sites, attracting many thousands of people. Simultaneously, the opposite is also possible - the mass media, for various reasons (for example, competitive) can produce a gloomy picture of any destination, artificially constructing a negative social perception of this place. In general, by creating images (often mythologized, simulatively constructed) of an attractive tourist destination, the mass media largely contribute to the commercialization of the tourism sector, including its ethnic and even religious types.

\section{Ethnic Tourism: Empirical Aspect of Religious Destinations}

Genuinely ethnic tours aimed at restoring historical consciousness are ideally conditioned by the history of the emergence and development of philosophical and 
ethical ideas, religious teachings, and traditions of a particular ethnic group. For example, turning to the Middle Ages, we find in Christianity and Islam many similar theological, anthropological, and philosophical ideas, which today are very promising for use in tourism in any country. At the dawn of both religions, these provisions were formed historically and continued concurrently in the Middle Ages. They were implemented in artifacts of art, architecture, Christian iconography, temple painting, and mosques' mosaics.

The Eastern Christian theology of the Byzantine Empire (especially after the iconoclasm polemic of the $8^{\text {th }}-9^{\text {th }}$ centuries) strongly influenced the sphere of art and architecture and the formation of religious and pilgrim tourism in the following centuries. Muslim pilgrimage objects are also associated with the religion's history and its justification in sacred texts. Thus, modern destinations of religious tourism (including pilgrimage) started forming deep in history and were associated with a particular multi-ethnic composition of the territory of the Byzantine Empire and the Caliphate. The contouring of sacred places of religious worship has always occurred in conjunction with the two world religions' teachings' corresponding canons. In Christianity, the theology of Fathers of the Eastern Church exerted a significant influence in this regard. Suffice to recall the famous Cappadocia Fathers' ideas - Basil of Caesarea, Gregory of Nazianzus, and Gregory of Nyssa - who developed the Trinity and Christological dogmas of Christianity. Cappadocia, which was part of the Byzantine Empire, was the center of theological and philosophical thought, monasticism, and asceticism. Many peoples lived there, replacing each other throughout periods - Persians, Armenians, Greeks, Seljuq Turks. In Byzantium, these peoples were united by a single religion. Currently, Cappadocia, located in Turkey, is one of the most famous world destinations for religious tourism and retains its unique status for the diverse ethnic groups and peoples of early Christianity.

In our opinion, the ethnic component must be taken into account when organizing religious tourism, and vice versa, knowledge of particular people's religious institutions, should take a decisive place in designing ethnic tours. Nowadays, objects of ethnic tourism quite often act as destinations for religious or pilgrim tourism. Speaking about the sites associated with the simultaneous formation of ethnic, cultural, and religious traits, one should name the villages of Gorno-Altaysk. Some ethnic groups living in the Uymon Valley of the Altai today constitute the Old Believers' tradition of Russian culture.

Since the second half of the 18th century, the Uymon Valley was inhabited by "Kerzhaks" "who fled from the reforms of Patriarch Nikon and formed the Old Believer community of this area. From that period to the present, the Russian people's original culture has been preserved in the Ust-Koksinsky District of the Altai Republic, making this unique region increasingly attractive for tourists. Historically, one of the first settlements in Altai - the village of Verkh-Uymon on the right bank of the Katun' River — was founded by Old Believers around 1786.

\footnotetext{
${ }^{1}$ The Kerzhaks are an ethnic and confessional group of the Russians.
} 
Russian explorer of this unique region, R.P. Kuchuganova, in her book devoted to Altai's peoples, writes about the first settlements of the Kerzhaks: "Old Believers humbly carried their cross as "foreigners" and derived their benefits from this. They easily established ties with the Altai tribes, mutually helped each other" [9. P. 19].

Since the time of the first Old Believers, the norms and traditions of this group's representatives have been preserved here, their culture and imperatives of life are transmitted orally and in writing. Religious customs and sacred writing of the Old Believers are fascinating for those who wish to see Russia's history directly in the medieval period. Some of these customs, which have survived to this day, constitute the ethnic-religious basis of the Old Belief: "The Old Believers treat the icons with deep reverence. Despite all the severities, persecutions, and hardships, they preserved the icons of the pre-Nikon writing. Icons and books were passed from hand to hand, from generation to generation. The one, who entered the house, before greeting the owners, had to bow to the icons. If you were jealous or angry during the day, do not get up to the icon... The Kerzhaks have preserved the "skete repentance", in which all believers, reading prayers, repent of their sins. The mentor reads the holy books, and the repentant pray" [9. P. 27].

We can still witness many of these traditions. In the daily routine of the Altai Old Believers, the culture of that distant era is kept unchanged, making the region especially attractive for travelers. In Verkh-Uymon, the indigenous Altaians and migrated Russians have always coexisted peacefully and created gradually together with the culture and image of their native land. The first settlers brought medieval Russian forms of buildings and houses to the valley, defining the appearance of the settlements of Uymon until now. Here a traveler can see the historical villages of the Russian North, the Volga region, Novgorod, and other areas. Traditions and beliefs that have been passing down for generations also determined a lot of inhome arrangements. Furthermore, they have not disappeared in the digital age. One of these ideas unites the Old Believers culture with nature: "Nobody determined the village's appearance. The house owner chose a place for his house the following way: he closed his eyes and threw a chip. If worms, bugs, and insects started living under it, you need to build here, the place is good: the cattle will be fertile, the house be in prosperity, the family be good" [9. P. 124-125].

The settlements of the Old Believers' religious community represent a promising direction for the development of ethnic tourism if it is organized to acquaint with the original culture of the inhabitants of the Altai and Siberia as a whole. Such historical corners of Russia are a treasure for truly ethnic, noncommercialized tourism since they preserve authentic culture and religion. The existence of such places as ethnic-religious directions of tourism is justified, among other things, philosophically: by joining the origins of Russian culture, which has preserved antique and medieval customs, a traveler comprehends contemporaneity in a qualitatively new way. The remoteness in time makes it possible to more objectively assess one's history, the hardships of the formation of Russian religious life, to understand the reasons for the emergence and preservation of the Old 
Believers Church and its followers. At the same time, any traveler inevitably thinks about their culture and identity when reflecting on the culture of the Altai Old Believers, i.e., the ethnic culture rooted in a totally different way of life. This is the essence, feature, and advantage of ethnic tourism.

The role of ethnic tourism in the modern world is significant since it aims to interact with the cultures and religions of numerous peoples. However, in our opinion, ethnic and spiritual directions and routes should not be linked to profit goals. The correlation of these types of tourism with commercial purposes deprives them of the central point - the focus on searching for the value foundations of other societies, on the knowledge of the culture of numerous peoples of our time. Tourists by the status are not mere clients paying for a tour. Above all, they have their own ethnic, religious, and civic identity, and seek to find manifestations of these in another nation's life, which means "satisfying the need in ethnicity" [6. P. $8]$. A traveling person enters a certain kind of interethnic and interreligious dialogue with people of other ethnic cultures and thus carries out the exchange of spiritual values. The responsibility of the organizers of ethnic routes to such a tourist is incredibly great: altogether, they become participants in intercultural dialogue on a global scale.

\section{References}

[1] MacCannell D. The Tourist: A New Theory of the Leisure Class. Berkeley, LA, London: University of California Press; 1999. Online. Access: 27, September. https://books.google.kz/books?id=6V_MQzy021QC\&printsec $=$ frontcover\&hl $=$ ru\#v $=$ one page \&q\&f=false

[2] Debord G. Society of the Spectacle. Detroit: Black and Red; 1983.

[3] Urry J. Global Complexity. Cambridge: Polity; 2003.

[4] MacCannell D. The Tourist: A New Theory of the Leisure Class. Moscow: Ad Marginem Press; 2016.

[5] Polyakova NV, Maximov DV. Ethnic Tourism as a Form of Interethnic Relations. Theoretical and Applied Aspects of Modern Science. 2014;(5-3).

[6] Berkovich NA. Ethnic Tourism - Cultural Meanings of Travel and Reconstruction of Historical Memory. Tourism Industry: Opportunities, Priorities, Problems and Prospects. Collection of Academic Writings and Proceedings of the International Scientific-Practical Conference. Moscow, May 12-13, 2011. Part 2. Moscow: MGIIT; 2011.

[7] Mihailova NV. Problematic of Ethnic Tourism in the Modern World. Vestnik MHEI. 2019;(4).

[8] Chistyakov D. Social Dimension of Mass-Media Space in Postmodern Epoch. Vestnik of Volgograd State University. Series 7: Philosophy. Sociology and Social Technologies. 2012;18(3).

[9] Kuchuganova RP. The Uymon Old Believers. Customs, Traditions, Culture. Cheboksary: Novoye Vremya; 2014.

\section{About the author:}

Chistyakova Olga V. - D.Phil., Professor, Department of History of Philosophy, RUDN University, Moscow, Russia (e-mail: chistyakova-ov@rudn.ru). 


\title{
Этнический туризм как познание Другого
}

\author{
О.В. Чистякова \\ Российский университет дружбы народов \\ Российская Федеращия, 117198, Москва, ул. Миклухо-Маклая, 6
}

Статья посвящена рассмотрению этнического туризма в контексте его значимости для постижения современных культур, uнblx по отношению к путешествующему человеку. В этом плане этнический туризм представлен с позиции познания Другого, - т.е. образа жизни какого-либо народа, его религиозных и этнических ценностей и традиций, исторического прошлого, мифов и сказаний, географических особенностей проживания. Таким образом, смыслы этнического туризма раскрываются в связи со стремлением человека открыть для себя иное культурное и социальное пространства. В то же время показано, как восприятие другой культуры влияет на осознание собственной идентичности туриста. Отмечается, что этнический туризм направлен на фиксацию отличительных черт и специфики жизни народа. Именно поэтому этот вид туризма в наибольшей степени способствует формированию образов и представлений об этнокультурном многообразии глобального мира. Автор обосновывает роль этнического туризма для установления диалога культур в современном мире. Выведены некоторые отличительные черты глобализации, в частности, непрекращающаяся мобильность путешествующих людей, диалогичность этнических групп и ценностное взаимообогащение народов. Определены некоторые теоретические подходы российских философов к исследованию этнического туризма. Акцентирована идея соотнесенности этнических культур и религий. В связи с этим богословские идеи раннего христианства обоснованы с точки зрения их воздействия на последующее формирование паломничества и на современную организацию религиозного туризма. Современное единство этнокультуры и религиозности ярко проявляется в уникальности старообрядческой традиции переселенцев-кержаков, проживающих на территории Горного Алтая. В статье делается вывод о том, что этничность должна учитываться при организации любого вида туризма, но особенно религиозного и паломнического типов.

Ключевые слова: философия туризма, этнический туризм, религиозный туризм, этническая культура, паломничество, Византия, Горный Алтай

Информация о финансировании и благодарности. Исследование выполнено при финансовой поддержке РФФИ в рамках научного проекта № 20-011-00045 А «Влияние этнокультурных, религиозных, коммуникативных, образовательных и миграционных факторов на развитие современной индустрии туризма: опыт социально-философского анализа».

\section{История статьи:}

Статья поступила 12.05.2020

Статья принята к публикации 11.08.2020

Для цитирования: Chistyakova O.V. Ethnic Tourism as Knowing Other // Вестник Российского университета дружбы народов. Серия: Философия. 2020. Т. 24. № 4. С. 720 -729. DOI: $10.22363 / 2313-2302-2020-24-4-720-729$

\section{Сведения об авторе:}

Чистякова Ольга Васильевна - доктор философских наук, профессор, Российский университет дружбы народов, Москва, Россия (e-mail: chistyakova-ov@rudn.ru). 